\title{
«ЗЕЛЕНІ» ІНВЕСТИЦІЇ ЯК ПРИКЛАД СОЦІАЛЬНО- ПЕРЕТВОРЮВАЛЬНОГО ВПЛИВУ У ФУНКЦІОНУВАННІ АВТОМОБІЛЬНОГО ТРАНСПОРТУ
}

Солопун Н.М., канд. екон. наук, доцент

Харківський національний автомобільно-дорожній університет

Пономарьова Н.В., канд. техн. наук, доцент

Харківський національний автомобільно-дорожній університет

Постановка проблеми. Серед сучасних тенденцій розвитку світового співтовариства важливе місце посідає Концепція сталого розвитку економіки, яка передбачає такий розвиток, при якому задоволення потреб нинішніх поколінь здійснюється без шкоди для можливостей майбутніх поколінь задовольняти свої власні потреби [1]. У рамках зазначеної концепції серед ключових задач розвитку певної економічної системи постає створення умов для сталого економічного розвитку, який може бути забезпечений шляхом ефективного використання економічного потенціалу зі значним збільшенням обсягів інвестицій та збільшенням обсягів впровадження інноваційних проектів, спрямованих на забезпечення подальшого зменшення показника углеродомісткості національної економіки. Величезну роль у цьому процесі відіграють енергетична і транспортні галузі.

Серед основних засада державної екологічної політики України $\epsilon$, зокрема, досягнення Україною Цілей сталого розвитку (ЦСР), які саме були затверджені на Саміті Організації Об'єднаних Націй зі сталого розвитку у 2015 році [2].

Аналіз останніх досліджень і публікацій. Питання впровадження елементів «зеленої» економіки $\epsilon$ у сфері наукових інтересів багатьох вітчизняних та закордонних вчених, а також низки міжнародних та наднаціональних організацій. Зокрема, Организация экономического сотрудничества и развития (ОЭСР) [3], Всесвітній банк [4], міжнародна юридична компанія Baker McKenzie [5] тощо. Крім того, вітчизняні вчені, такі як Анішенко В.О. [6], Пімоненко Т. В. [7], Люльов О., Чигрин О.Ю. [8] також звертають увагу на важливість зазначеного питання та підкреслюють недостатній рівень теоретичного висвітлення вказаної проблеми та необхідність подальшої іiі розробки.

Невирішені складові загальної проблеми. Трансформація галузей національної економіки з точки зору зменшення показника вуглецемісткості має відбуватися з урахуванням основних міжнародних тенденцій у цій площині. Сьогодні країни Європейського співтовариства прагнуть максимально скоротити викиди парникових газів, збільшуючи частку відновлюваної енергії. Зокрема, загальновідомим є той факт, що Європейська комісія запропонувала до 2050 року заборонити використання в містах автомобілів з бензиновим двигуном. деякі європейські країни визначили кордон по забороні автомобілів 3 бензиновим двигуном до 2030 року. 
Показник вуглецемісткості - це кількість діоксину вуглецю, який викинуто у атмосферу пр. виробництві однісї одиниці валового внутрішнього продукту [9].

Середня вуглецемісткість світового виробництва в 2018 році знизилася на $10 \%$ у порівнянні з 2010 роком [10], незважаючи на рекордне за десятиліття зростання попиту на енергію. Але поступовий перехід на альтернативні та поновлювані джерела енергії все ж таки дозволив отримати вищезазначені показники зменшення шкідливих викидів.

Величина показнику енергоємності первинної енергії в Україні складає 12 мегаджоулів на один долар США ВВП країни [11].

Рівень енергоємності первинної енергії - це співвідношення між пропозицією енергії до валового внутрішнього продукту, виміряним за паритетом купівельної спроможності за постійними цінами. Енергоємність - це показник того, скільки енергії використовується для виробництва однієї одиниці економічної продукції. Більш низьке відношення вказує на те, що для виробництва однієї одиниці продукції використовується менше енергії [11].

Формулювання цілей статті. Стан використання вуглецевих джерел енергії в України дуже «важкий». Тому постає нагальне питання переходу України до «зеленої» економіки, зокрема у галузі автотранспорту 3 використанням засад соціально-перетворювального впливу, тобто «зелених» інвестицій.

Виклад основного матеріалу дослідження. Спрямування вектору розвитку бізнес-моделі у «зелений» бік завжди достатньо тісно пов'язано 3 економією енергоносіїв (вуглецевого походження), i, як наслідок, з економією коштів. Зменшити власний «вуглецевий відбиток» можливо у різний спосіб перехід на альтернативне пальне, створення новітніх енергоефективних логістичних схем тощо.

Спираючись на засади Концепції сталого розвитку звернемо увагу на соціально-відповідальні або соціально-перетворювальні інвестиції. Саме вони мають потенціал до створення істотного впливу на сучасний стан енергоспоживання на автомобільному транспорті.

Сьогодні у сфері соціально-відповідальних інвестицій спостерігається швидке зростання. Спеціалісти у сфері управління інвестиційними портфелями сьогодні визнають, що впровадження інвестування на засадах соціальної відповідальності може зробити істотний вплив на рентабельність, вартість і ціну компаній. Соціально-перетворювальні або соціально-відповідальні інвестиції все більшою мірою стають нормою в області інвестицій, оскільки все більше інвесторів цікавляться екологічно чистими і «зеленими» продуктами, зокрема на автомобільному транспорті. Зокрема, певний інтерес представляють «зелені облігації» (green bonds) як інструмент залучення інвестиційних коштів у сучасні енергозберігаючі проекти, яких дуже потребує наша автотранспортна галузь.

«Зелені облігації» - це боргові інструменти, при випуску яких емітентпозичальник отримує від інвесторів фіксовану суму капіталу і направляє іiі на 
свої потреби, виплачуючи капітал інвестору, коли облігація погашається, а також узгоджену суму відсотків протягом терміну іiі звернення. Відмінною рисою «зелених облігацій» $\epsilon$ те, що залучені кошти використовуються для проектів, пов'язаних саме 3 впровадженням використання відновлюваної енергії, підвищенням енергоефективності, екологічно чистим транспортом або 3 подальшою побудовою низьковуглецевої економіки [12].

Пропонується наступне визначення, яке відображує сутність сучасного екологічного інвестування: «зелені» інвестиції - це такий прояв соціальноперетворювального впливу, який надає змогу дотримуватися вимог до функціонування сучасного транспортного підприємства в умовах декарбонізації світового виробництва.

Нагальною задачею, що постає перед пошукувачами інвестиційних коштів, зокрема транспортними підприємствами, є пошук надійних партнерів для здійснення емісії «зелених облігацій». Сьогодні такими партнерами на макрорівні слугуватимуть міжнародні організації, такі як Європейський інвестиційний банк, Всесвітній банк, національний уряд тощо. На макрорівні такими партнерами можуть бути трастові товариства, регіональна влада у рамках децентралізаційного процесу тощо.

Однією з задач пошукувачів інвестиційних коштів, тобто емітентів «зелених» облігацій, є забезпечення впевненості інвестора у дійсній екологічній спрямованості власної діяльності. Природоохоронне інвестування - це продукт, який до цих пір доводиться «нав'язувати» місцевим банкам 3 огляду на те, що активний попит на нього не формується природним чином. Зазначимо, що на сьогоднішній день не існує єдиного стандарту, що застосовується до моніторингу виконання засад, які продиктовані екологічною спрямованістю соціально-перетворювальних інвестицій. Але існують так звані Green Bonds Principles (GBPs), встановлені Міжнародною асоціацією ринку капіталу, $\epsilon$ прийнятими еталонами, яким слід більшість світових емітентів «зелених облігацій» [12]. Дотримання GBPs означає завірення інвесторів (як правило, покладаючись на незалежного експерта), що емітент відповідає певним стандартам щодо того, куди спрямовуються кошти від облігацій, як вибираються проекти і які звітності надаються інвесторам. Отже, незважаючи на відсутність чітких вимог до емісії «зелених облігацій», емітенти у будьякому випадку мають докладати значних зусиль для демонстрації потенційним інвесторам прагнення дотримання соціально-перетворювальної орієнтації i таким чином залучати інвестиційні кошти для подальшого впровадження інвестицій позитивного соціального впливу.

У свою чергу, стимулом для вкладання коштів у соціальноперетворювальні інвестиції для місцевих фінансових інститутів, можуть бути

- збільшення частки ринку - деякі місцеві фінансові інституції можуть вбачати в екологічному інвестуванні чи кредитуванні реальні можливості для розвитку бізнесу, тому що саме за умов посилення природоохоронного «тиску» та необхідності зниження вуглецемісткості національної економіки соціально- 
перетворювальне (зокрема, екологічне) інвестування може стати прибутковим ринком.

- позиціонування на ринку і позитивний імідж фінансових інститутів (потенційних інвесторів) - багатьма організаціями такого роду вже розроблено власні соціальні та екологічні програми, які вказують на дотримання етичних принципів та екологічних ідей тощо, які, зокрема, підвищують і рівень довіри до таких інституцій.

- ліквідність - використання екологічних кредитних ліній стало доброю нагодою для підтримки ліквідності через певну проблему 3 доступом до обмежених фінансових ресурсів. Саме соціально-перетворювальні інвестиційні проекти сьогодні мають більше шансів отримати фінансування та, як наслідок, збільшити рівень ліквідності для джерела інвестицій.

Висновки 3 проведеного дослідження. Сучасний напрямок екологічних інвестицій - перспективний вектор, який пов'язаний з виникненням нових видів економічної діяльності або навіть нових галузей економіки. Розвиток, соціально-перетворювальних інвестицій, наявним проявом яких $є$ екологічне інвестування та проекти зі зниження вуглецемісткості економіки представляє нове «вікно можливостей» для «зеленого» економічного зростання і вкладу країни в глобальний процес сталого розвитку людства. Використовуючи вже існуючий досвід соціально-перетворювального інвестування Європи та світу, ми вже сьогодні маємо можливість перейти до побудови енергетичних систем та систем надання транспортних послуг на принципах діджіталізаціi, децентралізації і найголовніше - декарбонізації. Однак, для такого переходу необхідно мати чіткий фокус на створенні «зеленого» ВВП як загальнонаціональної мети.

\section{Перелік посилань}

1. Report of the World Commission on Environment and Development: Our Common Future.

URL https://sustainabledevelopment.un.org/content/documents/5987our-commonfuture.pdf (дата звернення 03.11.19).

2. Закон України «Про основні засади (стратегію) державної екологічної політики України на період до 2030 року». URL : https://zakon.rada.gov.ua/laws/show/2697-19\#n14(дата звернення 04.11.19).

3. Экологическое кредитование в странах восточного партнерства европейского союза. URL : https://www.oecd.org/env/outreach/Environmentallending-EU-EaP-countries-Russian.pdf. (дата звернення 03.11.19).
4. Всесвітній
банк.
URL

http://documents.worldbank.org/curated/en/699051540925687477/pdf/131516-

RUSSIAN-PN-P168296-P164837-PUBLIC-Green-finance-Note.pdf

(дата звернення 04.11.19).

5. Юридична компанія Baker McKenzie. URL https://www.bakermckenzie.com (дата звернення 05.11.19). 
6. Аніщенко В.О. До питання щодо вдосконалення теоретикометодологічних засад екологічного інвестування. Актуальні проблеми економіки. 2007. Вип. 8. С. 175-183.

7. Пімоненко Т. В., Лущик К. В. Зелене інвестування: досвід СС для України. Вісник Сумського державного університету. Серія Економіка. 2017. № 4. С. 121-127.

8. Пімоненко Т. В., Люльов О. В., Чигрин О. Ю. Маркетинг зелених інвестіцій: Механізм колаборації между основними стейкхолдерами. Вісник Приазовського державного технічного університету. Серія: Економічні науки. 2018.

Вип. 36.

C. 214-220.

URL http://nbuv.gov.ua/UJRN/VPDTU_ek_2018_36_33 (дата звернення 05.11.19). 06.11.19).

9. Сайт компаніï Enerdata. URL : www.enerdata.net. (дата звернення

10. Інформаційне агентство Уніан. Викиди вуглекислого газу від світової енергетики виросли з-за зростання попиту на енергію. URL : www.unian.net/ecology/reduction/10495095-vybrosy-uglekislogo-gaza-ot-mirovoyenergetiki-vyrosli-iz-za-rosta-sprosa-na-energiyu.html (дата звернення 04.11.19).
11. Світовий
атлас
даних.
Енергетика.
URL https://knoema.ru/atlas/У краина/Энергоемкость (дата звернення 04.11.19).

12. Гутброд М., Храплива Ю. И., Володин С. Н. «Зеленые облигации» как новый финансовый инструмент и перспективы их внедрения в России. Валютное регулирование. Валютный контроль. 2017. Вип. 9. С. 44-52. URL : https://publications.hse.ru/mirror/pubs/share/direct/209317793 (дата звернення 07.11.19).

\section{References}

Our

1. Report from the World Commission on Environment and Development: https://sustainabledevelopment.un.org/content/documents/5987our-commonfuture.pdf (last accessed 03.11.19).

2. The Law of Ukraine «On the Fundamental Principles (Strategy) of the State Environmental Policy of Ukraine for the Period up to 2030» [Zakon Ukrayiny «Pro osnovni zasady` (strategiyu) derzhavnoyi ekologichnoyi polity`ky` Ukrayiny` na period do 2030 roku»], available at: https://zakon.rada.gov.ua/laws/show/269719\#n14(last accessed 04.11.19).

3. Environmental lending in the Eastern Partnership countries of the European Union [Ekology`cheskoe kredy`tovany`e $\mathrm{v}$ stranax vostochnogo partnerstva evropejskogo soyuza], available at: https://www.oecd.org/env/outreach/Environmental-lending-EU-EaP-countriesRussian.pdf (last accessed 03.11.19).
4. The
World
Bank,
available
at: http://documents.worldbank.org/curated/en/699051540925687477/pdf/131516RUSSIAN-PN-P168296-P164837-PUBLIC-Green-finance-Note.pdf (last accessed 04.11.19). 
5. Baker McKenzie Law Firm, available at: https://www.bakermckenzie.com (last accessed 05.11.19).

6. Anishchenko, V. A. (2007), «The question of improving the theoretical and methodological principles of environmental investment» [Do py`tannya shhodo vdoskonalennya teorety`ko-metodologichny`h zasad ekologichnogo investuvannya], Current problems of the economy, No. 8, P. 175-183.

7. Pimonenko, T. V., Lushchik, K. V. (2017), «Green investing: EU experience for Ukraine» [Zelene investuvannya: dosvid YeS dlya Ukrayiny'], Bulletin of Sumy State University. Economy series, No. 4, P. 121-127.

8. Pimonenko, T. V., Lyulyov, O. V., Chigrin, O. Yu. (2018), «Green Investment Marketing: A Collaboration Mechanism Between Major Stakeholders» [Markety`ng zeleny`h investicij: Mexanizm kolaboraciyi mezhdu osnovny`my` stejkholderamy`], Bulletin of the Azov State Technical University. Series: Economic Sciences, No. 36, P. 214-220, available at: http://nbuv.gov.ua/UJRN/VPDTU_ek_2018_36_33 (last accessed 05.11.19).

9. Enerdata website, available at: www.enerdata.net (last accessed 06.11.19).

10.Unian news agency. Carbon dioxide emissions from global energy have grown due to rising energy demand [Vy`ky`dy`vugleky`slogo gazu vid svitovoyi energety`ky` vy`rosly` iz-za zrostannya popy`tu na energiyu], available at: www.unian.net/ecology/reduction/10495095-vybrosy-uglekislogo-gaza-ot-mirovoyenergetiki-vyrosli-iz-za-rosta-sprosa-na-energiyu.html (last accessed 06.11.19).

11.World Data Atlas. Energy [Svitovy`j atlas dany`h. Energety`ka], available at: https://knoema.ru/atlas/Ukraine/Energy intensity (last accessed 04.11.19).

12.Gutbrod, M., Khrapliva, Yu. I., Volodin, S. N, (2017), «Green bonds» as a new financial instrument and prospects for their implementation in Russia [Zelenye obligatsii» kak novyy finansovyy instrument i perspektivy ikh vnedreniya v Rossii], Currency regulation. Currency control, No. 9, P. 44-52, available at: https://publications.hse.ru/mirror/pubs/share/direct/209317793 (last accessed 07.11.19).

\section{РЕФЕРАТИ РЕФЕРАТЫ ABSTRACTS}

\section{УДК 658+330.322.4+330.322.54+330.59; JEL D64:E220:I3 \\ Солопун Н.М., Пономарьова Н.В. «ЗЕЛЕНІ» ІНВЕСТИЦЇ̈ ЯК ПРИКЛАД СОЦІАЛЬНО-ПЕРЕТВОРЮВАЛЬНОГО ВПЛИВУ У ФУНКЦІОНУВАННІ АВТОМОБІЛЬНОГО ТРАНСПОРТУ}

Mema: Метою статті є подальша розгляд питання переходу України до «зеленої» економіки, зокрема у галузі автотранспорту з використанням засад соціально-перетворювального впливу, тобто «зелених» інвестицій. Методика дослідження: в роботі використано наступні методи наукового дослідження: систематичний та порівняльний аналіз для наукових джерел на основі методів порівняння, систематизації та узагальнення; абстрактно-логічного аналізу - для обгрунтування сутності «зеленого» інвестування та необхідності впровадження соціально-перетворювальних інвестицій; узагальнення результатів аналізу і 
логічної генерації висновків. Результати: Розвиток, соціальноперетворювальних інвестицій, наявним проявом яких є екологічне інвестування та проекти зі зниження вуглецемісткості економіки представляє нове «вікно можливостей» для «зеленого» економічного зростання і вкладу країни в глобальний процес сталого розвитку людства. Використовуючи вже існуючий досвід соціально-перетворювального інвестування Європи та світу, ми вже сьогодні маємо можливість перейти до побудови енергетичних систем та систем надання транспортних послуг на принципах діджіталізаціі, децентралізації і найголовніше - декарбонізації. Однак, для такого переходу необхідно мати чіткий фокус на створенні «зеленого» ВВП як загальнонаціональної мети. Наукова новизна: Отримано подальший розвиток теоретичних аспектів впровадження соціально-перетворювальних інвестицій у транспортну галузь за допомогою впровадження засад «зеленого» інвестування та емісії «green bonds»; запропоновано авторське визначення поняття «зелені» інвестиції. Практична значущість результатів проведеного дослідження полягає у тому, що удосконалені теоретичні аспекти нададуть змогу приймати більш обгрунтовані рішення у процесі інвестиційної діяльності.

Ключові слова: «зелені» інвестиції; соціально-перетворювальний вплив; «green bonds»; декарбонізація; транспорт.

\section{УДК 658+330.322.4+330.322.54+330.59; JEL D64:E220:I3}

Солопун Н.М., Пономарева Н.В. «ЗЕЛЕНЫЕ» ИНВЕСТИЦИИ КАК ПРИМЕР СОЩИАЛЬНО-ПРЕОБРАЗУЮЩЕГО ВЛИЯНИЯ
ФУНКЦИОНИРОВАНИЕ АВТОМОБИЛЬНОГО ТРАНСПОРТА

Цель: Целью статьи является дальнейшее рассмотрение вопроса перехода Украины к «зеленой» экономике, в частности в области автотранспорта, с использованием принципов социально-преобразующего воздействия, то есть «зеленых» инвестиций. Методика исследования: в работе использованы следующие методы научного исследования: систематический и сравнительный анализ для изучения научных источников на основе методов сравнения, систематизации и обобщения; абстрактно-логического анализа - для обоснования сущности «зеленого» инвестирования и необходимости внедрения социально-преобразующих инвестиций; обобщения результатов анализа и логической генерации выводов. Результаты: Развитие социальнопреобразующих инвестиций, проявлением которых является экологическое инвестирование и проекты по снижению углеродоемкости экономики, представляет новое «окно возможностей» для «зеленого» экономического роста и вклада страны в глобальный процесс устойчивого развития человечества. Используя существующий опыт социально-преобразующего инвестирования Европы и мира, мы уже сегодня должны перейти к построению энергетических систем и систем предоставления транспортных услуг на принципах диджитализации, децентрализации и самое главное - декарбонизации. Однако, для такого перехода необходимо иметь четкий фокус на создании «зеленого» ВВП как общенациональной цели. Научная новизна: Получено дальнейшее 
развитие теоретических аспектов внедрения социально-преобразующих инвестиций в транспортную отрасль посредством внедрения принципов «зеленого» инвестирования и эмиссии «green bonds»; предложено авторское определение понятия «зеленые» инвестиции. Практическая значимость результатов проведенного исследования заключается в том, что усовершенствованные теоретические аспекты предоставят возможность принимать более обоснованные решения в процессе инвестиционной деятельности транспортного предприятия.

Ключевые слова: «зеленые» инвестиции; социально-преобразующее влияние; «green bonds»; декарбонизация; транспорт.

\section{UDC 658+330.322.4+330.322.54+330.59; JEL D64:E220:I3}

Solopun N.M., Ponomaryova N.V. GREEN INVESTMENT AS AN EXAMPLE OF SOCIAL-TRANSFORMING INFLUENCE IN THE FUNCTIONING OF MOTOR VEHICLES

Purpose: The purpose of the article is to further consider the transition of Ukraine to the «green» economy, in particular in the field of motor transport using the principles of social and transformative influence, namely «green» investments. Methodology of Research: in the article the following research methods are used: systematic and comparative analysis for scientific sources based on methods of comparison, systematization and generalization; abstract-logical analysis - to substantiate the essence of «green» investment and the need to introduce socialtransformative investments; generalization of results of analysis and logical generation of conclusions. Findings: The development of socially-transformative investments, the manifestation of which is environmental investment and carbon reduction projects, represents a new «window of opportunity» for «green» economic growth and the country's contribution to the global process of sustainable human development. Using already existing experience of social and transformative investing of Europe and the world, today we have the opportunity to move to the construction of energy systems and systems of rendering transport services on the principles of dititalization, decentralization and most importantly - decarbonisation. However, such a transition requires a clear focus on creating green GDP as a nationwide goal. Originality: The further development of theoretical aspects of the introduction of social-transformative investments in the transport industry was obtained through the introduction of the principles of green investment and green bonds; The author definition of green investments were proposed.

Practical value of the results of the study is that advanced theoretical aspects will allow for more informed decisions in the investment process.

Key words: «green» investments; social-transformative influence; «green bonds»; decarbonisation; transport. 


\section{Відомості про авторів / Сведения об авторах / About the Authors}

Солопун Наталія Миколаївна - кандидат економічних наук, доцент, Харківський національний автомобільно-дорожній університет, доцент кафедри економіки i підприємництва, м. Харків, Україна; e-mail: solopunnataliya@gmail.com; ORCID ID: https://orcid.org/0000-0002-8958-9303. Моб. 066-049-09-17.

Солопун Наталья Николаевна - кандидат экономических наук, доцент, Харьковский национальный автомобильно-дорожный университет, доцент кафедры экономики и предпринимательства, г. Харьков, Украина.

Solopun Nataliya - Candidate of Sciences (Economics), Associate Professor, Kharkov National Automobile and Highway University, Associate Professor at the Department of Economics and Entrepreneurship, Kharkiv, Ukraine.

Пономарьова Надія Володимирівна - кандидат технічних наук, доцент, Харківський національний автомобільно-дорожній університет, доцент кафедри транспортних систем і логістики, м. Харків, Україна; e-mail: nadin_tt@ukr.net; ORCID ID: https://orcid.org/0000-0003-3972-173. Моб. 067-577-19-81.

Пономарева Надежда Владимировна - кандидат технических наук, доцент, Харьковский национальный автомобильно-дорожный университет, доцент кафедры транспортных систем и логистики, г. Харьков, Украина.

Ponomaryova Nadiya - Candidate of Sciences (Technics), Associate Professor, Kharkov National Automobile and Highway University, Associate Professor at the Department of Transport Systems and Logistics, Kharkiv, Ukraine. 